\title{
Geographical Mobility and Family Life: Comparing Generations from a Life Course Perspective
}

\author{
Karin Wall, Sofia Aboim, Vasco Ramos, Cátia Nunes
}

\begin{abstract}
Geographical mobility is a well-established trend in European societies, and social theorists have put forward the hypothesis that mobility patterns have an impact on family trajectories and on their processes of pluralisation and individualisation. Using a life course perspective, the main aim of this article is to provide evidence of the impact of geographical mobility on family life in Portuguese society. The mobility and family trajectories of three different generations in their early adulthood are analysed, with results pointing to a diversity of trajectories as well as to relevant connections between mobility variables and family trajectories. The article draws on data from a national survey on life trajectories conducted in 2010 on a representative sample of men and women $(n=1,500)$ from three generations (born between 1935 and 1940; 1950 and 1955; and 1970 and 1975; n=500 per generation). Based on sequence and cluster analyses, we were able to identify seven patterns of mobility trajectories and four main types of family trajectories across the three generations. These reflect not only the biographies of individuals within our sample, but also the geographical and family changes that have been taking place in Portugal over the past few decades. Drawing on multinomial regression analysis, the article seeks to disentangle the complex linkages between mobility and family trajectories. To this end, we adopted a double angle approach by linking these two variables as predictors of each other alongside other key socio-demographic variables and life course events. The main findings reveal that geographical mobility is a significant predictor of family trajectories, even if its effects are dualistic: Mobility may work as a facilitator of standardised family trajectories (early transition to parenthood, for example), but it also predicts a higher probability of "non-linear" family trajectories. On the other hand, family trajectories are weak predictors of mobility trajectories. The latter are predicted by variables that reflect structural constraints, such as unemployment, but gender and generation effects also play an important role and provide evidence that mobility trajectories are anchored in specific historic and social contexts. Finally, we were also able to link geographical mobility to individualisation processes by examining its impact upon specific life course events related to family and gender relations.
\end{abstract}


Keywords: Geographical mobility · Migration patterns · Family trajectories · Life course $\cdot$ Individualisation

\section{Introduction}

Recent research and discussion about demographic trends and families in Portuguese society has led to a consideration of the crucial role of migration in the processes of modernisation of family dynamics over the last few decades. Theorists of modernity and post-modernity establish linkages between the importance of geographical mobility, in particular during the second half of the twentieth century, and the trend towards pluralisation and individualisation in families (e.g. Beck 2000). This trend is seen to unfold in various ways. A widely-accepted hypothesis is that the accumulation of resources through migration facilitated marriage and family formation, leading to a marked increase in the marriage rate during the 1960s and 1970s (e.g. Wall 2005). However, a second hypothesis is that the opposite effect is also pronounced: Migration, in particular male-led emigration or return migration from the former Portuguese colonies in Africa - which became independent countries after the 1974 democratic revolution - or from Europe, may be assumed to have a number of disruptive effects on conjugal life, leading to more and more varied transitions in family life (separation and divorce, lone parenthood, living alone). Therefore, a third assumption is that geographical mobility may also lead to individual autonomy, facilitating not only more egalitarian gender roles in the family, in particular the participation of women in the labour market, but also a stronger focus on the postponement of family formation or the transition to parenthood.

Drawing on a life course approach, the main aim of this article is therefore to provide more systematic research evidence on the impact of geographical mobility - defined in this paper as migration ${ }^{1}$ - on family life. On the basis of a national survey on the life course in Portuguese society, ${ }^{2}$ we sought to describe geographical mobility patterns of three different generations and analyse the interconnections between the latter and individuals' family trajectories. The article's main concern is to examine the extent to which geographical mobility is indeed related to individuals' family lives, to identify the specific effects of mobility on family trajectories and to assess whether these effects are the same across social and historical time.

1 Geographical mobility includes not only migration but also other forms of mobility, such as commuting or overnighting. See, for instance, Limmer and Schneider 2008.

The "Family trajectories and social networks: the life course in an intergenerational perspective" project is funded by the Portuguese Science Foundation and coordinated by Karin Wall at the Institute of Social Sciences (2008-2011). This article derives from this larger research project on family trajectories and social networks in Portugal, the main aims of which are to reconstitute the life trajectories of individuals from different generations through a multidimensional approach to the life course, which combines different spheres and aspects: family life (coresidence, conjugality/partnerships and parenthood), educational and professional trajectories, residential and geographical mobility. 
Our particular emphasis on historical time was key to our choice of three specific groups of individuals, each of which experienced major historical changes and social disruptions, even turmoil, across their life courses. Therefore, we perceive birth cohorts as generations, which entail a common historical location and also the experience of a common subjectivity (Mannheim 1952 [1927]) propelled by the massive societal transformations that occurred in Portuguese society (e.g. Kertzer 1983). As A/win and McCammon (2003) note, generations and cohorts are concepts often used interchangeably in spite of their different meanings. A distinction should however be made here. Both focus on the location of individuals in a given historical time, but by resorting to the idea of "a generation", we wish to underline not only the strength of history as an external constraint, but importance is also given to the shared biographical experiences that moulded both the potential life courses of individuals and the ways in which they have constructed specific and relatively similar worldviews (e.g. Eyerman/Turner 1998; Corsten 1999). Although generations are widely discussed and often criticised because of their lack of objectivity, when compared to the concept of cohort, we agree with White (1992), who stresses that cohorts should only be interpreted as generations when they subjectively show sufficient coherence. In the Portuguese case, and in this analysis, our methodological strategy was designed to reconstruct generations by taking into account both structural constraints and significant subjective experiences (e.g. living under an authoritarian regime; experiencing a democratic revolution in 1974; living in conditions of political freedom and economic growth).

All in all, by exploring and comparing the life courses of three different historical generations, we expect to convey additional knowledge on the inter-connections between geographical mobility and family life. Bearing this in mind, it is necessary to connect family and biographical time to social and historical time (Elder 1985, 1994), as well as to examine the main factors influencing each generation of individuals (Mayer 2004). Our methodological strategy therefore implies combining a macro approach (which places life trajectories and transitions in wider generational and social contexts) and a micro approach (centred on the individual), which may allow us to observe the flow of diversified biographies in each generation (Elder et al. 2003).

The article is divided into four parts. The first briefly describes the main migration flows in Portuguese society over the last few decades. The second examines the life trajectories of individuals across the three generations included in the study, focusing in particular on patterns of geographical mobility, their intrinsic characteristics, and the main types of family trajectories. The third draws on multinomial logistic regression analyses to examine the connection between individuals' geographical trajectories and family trajectories. Geographical mobility is considered both as an independent variable, which is expected to exert a number of effects upon family life, and as a dependent variable. Through this double analytical strategy, we seek not only to test our main hypothesis - e.g. the impact of geographical mobility on family trajectories - but also to identify the factors that lie behind mobility events throughout the life course. In the fourth section, we examine the relationships between geographical mobility and a number of key events related 
to the process of individualisation (ranging from living alone or as a lone parent to having gone through a divorce). This analysis will allow us to explore the effects of geographical mobility upon particular key life course events and stages, which are of paramount importance for testing the hypothesis that geographical mobility has also been a driver of individualisation, even if its role in promoting entry into conjugal and parental life is anticipated in our study. Our main goal is thus to assess, from a variety of angles, the extent to which geographical trajectories - which can be of intense mobility or, on the contrary, of immobility across the life course - have had a real impact on family patterns over time and across generations, and also to single out the specific effects that may be associated with the dynamics of family life in each generation.

\section{Geographical mobility and family life in Portuguese society: an historical overview}

Since the end of the nineteenth century, geographical mobility has been a major structural process of change in Portuguese society, leaving indelible marks both on the lives of all of those who have been through the experience of migration and on the organisation of social and family life. Migration is not a recent fact, deriving mainly from contemporary globalisation processes, but rather a phenomenon with a long history, thereby representing one of the key forces of change in Portuguese society during the twentieth century (Wall 1982; Arroteia 1983; Rocha-Trindade 1984; Serrão 1985; Peixoto 1999, among others). Economic as well as social, religious and political factors have been the main drivers of emigration and the large Portuguese Diaspora in the five continents. However, the patterns of Portuguese migration have gone through important changes over time.

In the first half of the twentieth century, Portuguese emigrants were mainly part of the intercontinental flows that had their roots in the previous century, and which have contributed over time to the development of individualisation processes, as well as transforming traditional societies with familialistic regimes into increasingly conjugalist and individualistic societies, as Norbert Elias (1993) has noted. Brazil, Argentina, Venezuela, among other South American countries, and the US, alongside Canada, were the most important destination countries for migration. The poor living conditions and the lack of opportunities for job mobility led thousands of people to look for a better life abroad, a tendency that increased strongly after the Second World War and particularly in the 1960s, when a three-front colonial war exhausted the already scarce resources of the impoverished rural areas of the country.

Countering the earlier transcontinental flows of emigrants, the migration patterns of the second half of the twentieth century developed along three main lines: emigration, internal migration and immigration. Emigration being the first significant trend, official statistics show that around 1.5 million individuals left Portugal between 1958 and 1974. Some went to the Portuguese African colonies (particularly after 1961, paradoxically the year when the national liberation wars against Portuguese rule began in those territories), but most of them emigrated within Europe, 
mainly to France but also to Germany and Luxembourg. Emigration declined gradually during the 1970s, due not only to the economic crisis of 1973 but also to the political changes in Portugal, namely the 1974 military coup that overthrew the dictatorial political regime of the Estado Novo, which lasted for nearly fifty years. In the 1980s and 1990s, individuals continued to head for a number of European countries, particularly Switzerland, Germany and Luxembourg (Silva 1992; Marques 2008). A second major trend was internal migration, mainly from rural areas to the cities. Until the 1950s, most of the Portuguese population was in the primary sector, but new job opportunities started to be available in the industrial sector during the 1960s and 1970s. Entire families moved to the rapidly-developing urban areas in search of a better standard of living. This represented a movement from the rural hinterland to the coastal and increasingly urbanised areas and cities, a geographical pattern of mobility that is reflected in the country's regional outline. The exodus from rural society was one of the most significant processes of change in Portuguese society, and its impact on family life follows closely the patterns that Shorter (1995) has described so well in his The Making of the Modern Family. Immigration has been a third major trend. However, compared to its long emigration history, Portugal has only recently become a country of immigration. The most important phenomenon after 1974 was the return of the colonial settlers in Africa (Pires et al. 1987). With decolonisation, nearly half a million people arrived in Portugal and had to be integrated into a new, but still frail, democratic society. In the 1980s, some of those who had worked for several years in France or other European countries also came home, normally after retiring from active work. And lastly, from the mid-eighties onwards, Portugal began to see an increasing and diversified flow of immigrant workers, first from Brazil, and then from other sending countries in the late 1990s (Ukraine, Moldavia, Russia, Romania, China, Pakistan and India) (Pires 2002; Baganha et al. 2004).

These major migration flows were permeated by different gender dynamics and family strategies. The early intercontinental flows were mainly a case of family mobility, with both members of the couple and their offspring leaving the country together to the Americas or to the Portuguese former colonies. Most families left Portugal with a lifelong project. In this sense, for quite a few of the "returnees", the return from Africa represented a major disruptive turning point in their lives, leading them to a forced reorganisation of family and work. The same long-term familybased rationale can be applied to the thousands who migrated from rural to urban areas. On the other hand, the typical male breadwinner emigration, where the man leaves his family behind, has been linked to intra-European geographical mobility. Nonetheless, family reunion became more common from the mid-1960s onwards (Arroteia 2001). This trend is well expressed not only in the increase in the number of female emigrants - 40,0 percent in 1966; 40.8 percent in 1967 and 53.5 percent in 1968 - but also in the age structure of those who left the country. At this time, a significant proportion of the emigrant population was made up of children below the age of 14. In spite of a certain predominance of the male adult and a low-qualified model of emigration, family reunion became increasingly important.

In spite of its importance in the restructuring of social stratification and family patterns, Portuguese migration still lacks a more extensive analysis, particularly 
regarding the impact of migration on family life. Moreover, a model that integrates a life course perspective is still a task to be undertaken and a theoretical problem to be tackled in the empirical study of Portuguese society (e.g. Kulu/Milewski 2007; European Foundation for the Improvement of Living and Working Conditions 2005; Green/Canny 2003; Geist/McManus 2008). Little is known about the interconnections between migration flows and the organisation of family life, even though there are a number of studies that point to the existence of different migration patterns.

\section{Data and methods}

Data for analysis of geographical and family trajectories is taken from a national survey conducted in 2010 and based on a representative sample of men and women $(n=1,500)$ belonging to three different generations (born between 1935 and 1940; 1950 and 1955; and 1970 and 1975; $n=500$ per generation). The sample corresponds to a stratified probability sample of Portuguese men and women residing in the country (Response rate equals 60 percent and overall sampling error corresponds to \pm 2.5 percent; $\alpha=0.05$ ). Foreigners and individuals with mental or physical disabilities were deemed to be ineligible. Interviews were conducted by a group of trained interviewers in the respondents' households following the PAPI method.

Our three-generation sample was built in accordance with key principles of the life course theory, as defined by Elder (1994). From this perspective, we consider that individuals can become active agents of their own life course. Individuals' biographies are simultaneously defined by the context in which they live, and by the ways in which they are able to shape and act upon the different external constraints and opportunities available to them in a given historical context. Therefore, the life course approach allowed us to take into consideration both macro and micro variables in the analysis of individuals' geographical mobility and family trajectories across generations. Furthermore, in accordance with recent developments in life course analysis (Abbott 2001; Sapin et al. 2007), we have adopted an inductive methodological strategy that allows monitoring the sequence of events that are a constituent of each individual's biography rather than deriving all the possible range and variety of life courses from the historical environment in which individuals lived and were socialised. However, we still grant a key role to historical processes insofar as macro-social changes set the constraints suffered by, and also the opportunities available to, each generation of individuals.

In line with this view, our three-generation sample reflects major historical processes that took place in Portuguese society and have marked men's and women's biographies. The first group of individuals represents a generation born before World War II and raised in the heyday of Salazar's right-wing authoritarian and coIonialist regime of the Estado Novo (1926-1974). The second generation is the postwar generation, which entered adult life in the late 1960s, during the final period of the authoritarian regime. This middle generation lived through the troubled times of the transition to democracy, also undergoing the impact of the major changes that occurred in economic, social, political and cultural structures. Finally, the third 
generation represents an age group that entered adult life in the post-EU-accession period. The beginning of the 1990s was a time of stabilisation and consolidation in terms of the massive social changes that had shaken Portuguese society in earlier decades.

The analysis of geographical and family trajectories across and within generations implied three important methodological procedures:

First, with regard to intergenerational comparison, our analysis of both geographical and family trajectories across the three generations considers individuals' life courses from age 18 to age 35 . This procedure was necessary in order to compare the generations over a similar life period (Iongitudinally), that is early adulthood. On the other hand, it should be noted that we are simultaneously dealing with biographical events (for instance, the number of times a given individual moved from one geographical location to another in this age period) and with generational differences across historical time. Closely following key tenets of life course theory, these two angles of analysis should be taken into account in the interpretation of the results of our study.

Secondly, in order to reconstitute geographical mobility trajectories, we took into account a number of biographical variables (for instance, the occurrence of migration, the number of migration movements, the timing of mobility) and identified the geographical locations in which each individual resided every single year between the ages of 18 and 35. Moreover, it should be mentioned that to capture geographical trajectories, we focused on "residential" mobility and took as an elementary variable the place of residence (the "municipality" of residence in Portugal or, if abroad, the country of residence). Locations were therefore classified in accordance with a number of combined criteria: the "number of inhabitants" in each municipality, proximity/distance from the coast, urbanisation density and country. ${ }^{3}$ Nine categories were used: Rural Inland, Rural Coast, Urban Inland, Urban Coast, Suburban, Major Cities, Colonies, Europe and Rest of the World. All the individuals in the sample were included in this analysis, whether they experienced geographical mobility or not. As a result, this procedure allowed us to observe geographical trajectories from different angles: the mobility or immobility of individuals throughout the biographical period of early adulthood and the changes from generation to generation. We were able to capture the internal exodus from rural regions to densely-populated urban areas as well as the emigration flows to and from European countries, non-European countries and the former Portuguese colonies. However, it should be noted that our methodological option revealed geographical trajectories at the intersection of two different criteria: the mobility or immobility of

3 The National Statistical Institute Nomenclature of Units for Territorial Statistics (NUTS3) was used to classify each location in terms of Inland vs. Coastal. All locations situated in a NUTs bordering or less than $20 \mathrm{~km}$ from the coast, were labelled Coastal, others being Inland. Regarding urbanisation density, the cities of Lisbon and Porto were classified as Major Cities; locations in the metropolitan areas of larger cities were classified as Suburbs; Cities outside metropolitan areas of larger cities were classified as Urban; other locations in Portugal were classified as Rural; the remaining locations are self-explanatory. 
individuals, thereby drawing a distinction between those who "stayed" and those who "moved", and the geography of residence in contrasting social environments (such as rural versus urban).

Thirdly, family trajectories were reconstituted by analysing household living arrangements. As above, data were organised sequentially by considering, for each individual, all the changes in living arrangements from ages 18 to 35 . Fourteen possible configurations where chosen, namely: living with one parent; living with both parents (with or without siblings); living only with siblings; living with other kin; living with parents and other kin; living only with non-kin; living with parents and step-parents; living as a couple; living as a couple with children; living as a couple with children and others; living as a couple and with others; living as a lone parent; living as a lone parent with others; and living alone.

Our analytical strategy followed a three-step pathway:

Firstly, we identified two types of life trajectories for the three generations: famiIy and mobility trajectories. The optimal matching method (e.g. Gauthier et al. 2009) was the main statistical tool used in this first procedure. Data on trajectories was therefore analysed using the TraMineR package for Sequence Analysis in R software (Gabadinho et al. 2008; Ritschard et al. 2008). In accordance with this method, each trajectory was sorted and analysed as a whole in order to characterise its evolution in each generation. Following this procedure, mobility and family trajectories were clustered using an agglomerative clustering algorithm (Ward's method). Since our purpose was to identify the common types of trajectories, the clustering procedure was carried out for the whole sample. The types of trajectories will be described in the section below.

A second key analytical step focused on the complex interconnections between geographical and family trajectories. Multinomial regression ${ }^{4}$ procedures enabled us to measure the impact of different patterns of mobility on family life. Although we consider this as our key hypothesis, we also used an additional multinomial regression to test the inverse statistical connection in order to find out to what degree family life, among other factors, could also exert an influence on mobility trajectories. This procedure allowed us to identify the main factors that predict the likelihood of having a particular type of mobility trajectory. Through this approach, we took into account the timing of events and their sequential order over the life course: That is to say, family dynamics may be drivers of mobility at earlier stages of the life course while also being affected by geographical mobility later on. To sum up, we analysed the impact of geographical mobility on the family, but also set out to portray the inverse connection, that is the ways in which certain family and work events may function as drivers for mobility in the three contrasting generations.

4 The multinomial logistic regression model is a generalisation of the binary logistic regression model. The dependent variable in this model corresponds to a nominal variable with three or more categories. The results are interpreted by taking into consideration a reference category of the dependent variable, which can be previously defined in the model (Menard 2002). 
We included a number of key variables in our regression models. Alongside the types of geographical and family trajectories, we measured the predictive influence exerted by generational and gender coordinates, the impact of schooling careers and, most importantly, the effect of certain events and life stages linked to employment trajectories. The number of years of unemployment was also included in the regression models due to the paramount importance often attributed to unemployment as a key trigger of emigration (e.g. Massey 1988).

Finally, in a last step, the aim was to record the effects of mobility trajectories on individualisation processes by taking into consideration a few specific life course events and experiences, such as living alone, childlessness, divorce or lone parenthood. The analysis of these biographical events was important in order to examine, in another light and from a different methodological perspective, the hypothesis that links geographical mobility to individualisation processes in family life.

\section{$4 \quad$ Results}

\subsection{Geographical mobility and family trajectories}

The cluster analysis that resulted from the optimal matching procedures enabled us to identify, for the three generations in our sample, seven clusters of geographical mobility among young adults aged between 18 and 35 (see Fig. 1 and Table 1). These seven types of geographical trajectories reveal the location of residence of different individuals as well as the intensity of mobility ${ }^{5}$ that defines the trajectories clustered in each of the seven types. As a result, we measured two crucial processes that cut across generations by both analysing the mobility of people in their biographies and putting forward key changes in the geographical organisation of Portugal over the past few decades.

The first cluster revealed by the analysis, namely the suburban type, includes mainly individuals who found themselves in the outskirts of Lisbon and Porto - the two major Portuguese cities - during their early adulthood. These individuals (in total 22 percent of the sample) may either always have lived in suburban areas around Lisbon or Porto or migrated from the city to its outskirts at some point in their lives. Although this cluster has a high proportion in the younger generation, the biographical movement of migration from the "big cities" to the surrounding suburban areas is more visible among individuals from the older generation. On average, older individuals lived nearly 3 years in the city and 13 years in the suburbs. In the middle and younger generations, the average period of residence in the city decreases (to less than 2 years), with individuals having spent most of their young adulthood in suburban areas. However, in spite of the generational differences that cut across this pattern (which increased considerably in the middle and younger generations, with

5.2 percent of individuals experienced mobility between ages 18 and 35 . This means that 64.8 percent of individuals in our sample did not experience mobility in this period of their lives. 
Fig. 1: Trajectories of geographical mobility (under 19 to under 36 years), by cluster $^{*}$
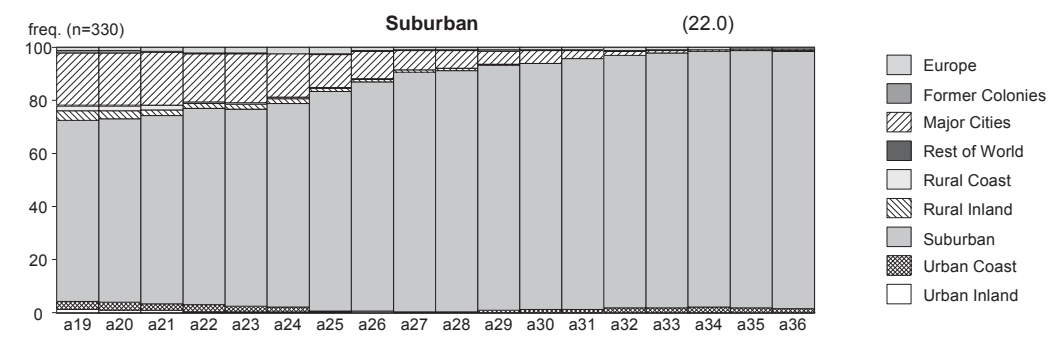

freq. $(n=193)$

Major Cities

(12.9)
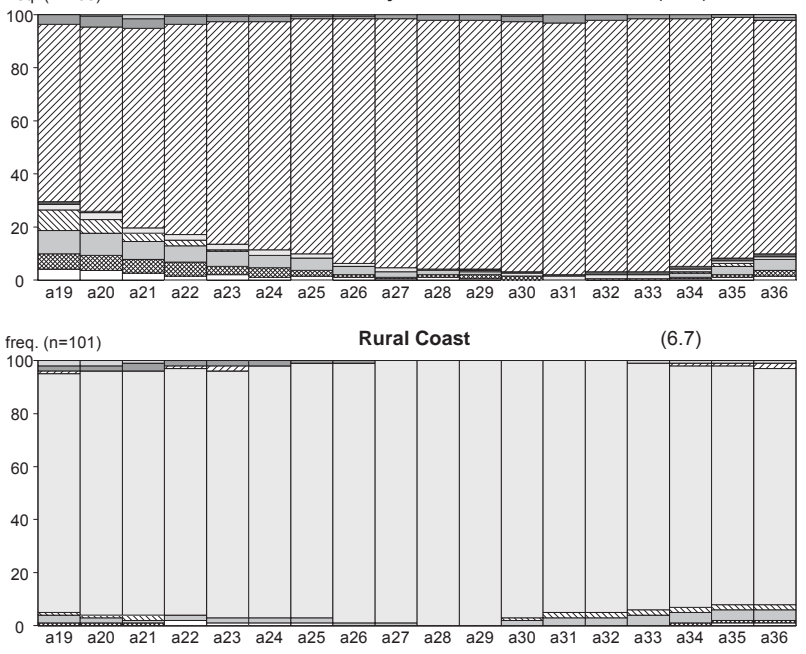

0 a19 a20 a21 a22 a23 a24 a25 a26 a27 a28 a29 a30 a31 a32 a33 a34 a35 a36

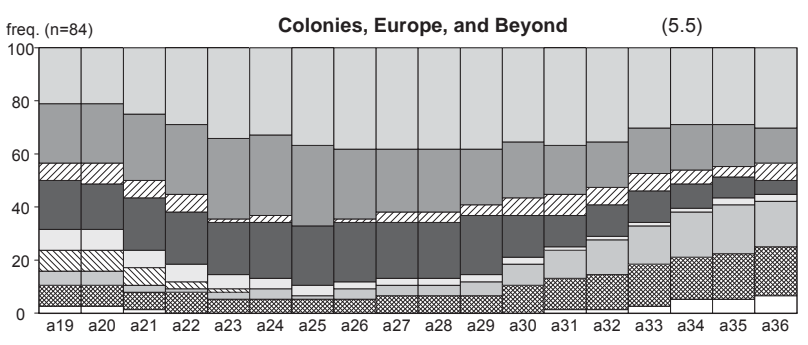

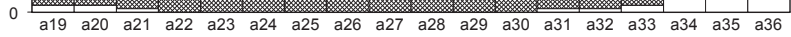

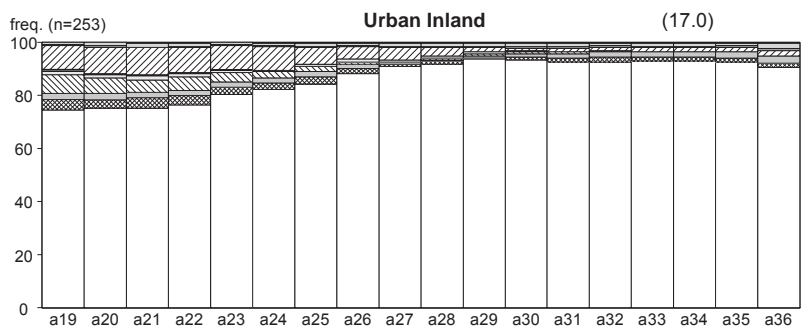




\section{Continuation fig. 1}

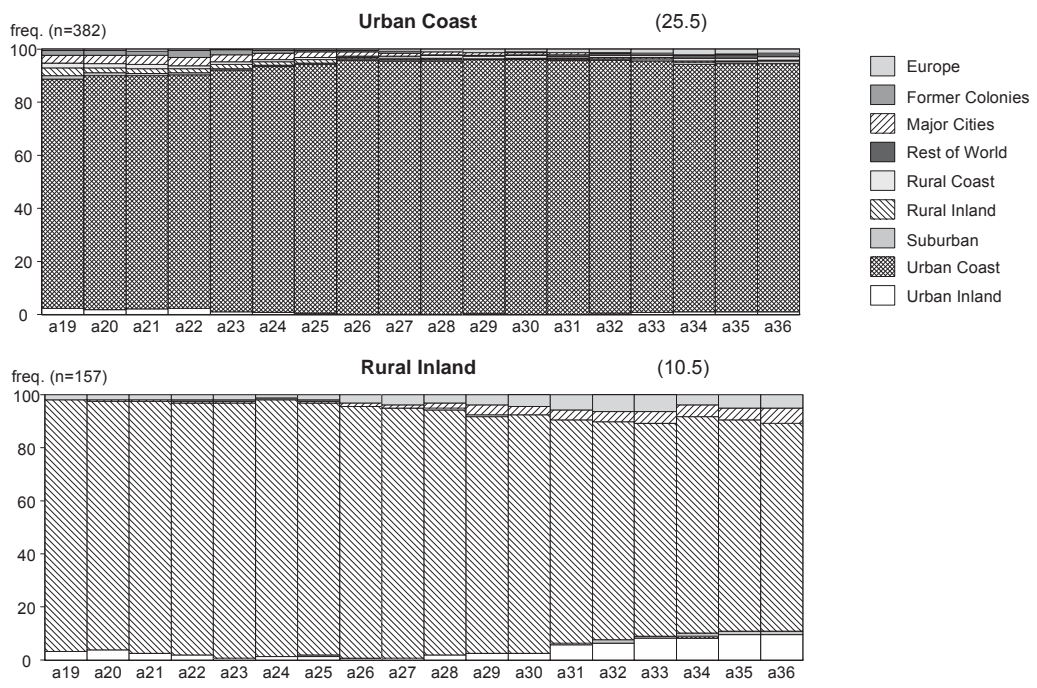

* Participants were asked for their place of residence between ages 18 and 35. The original categories are: Europe, Former Colonies, Major Cities, Rest of the World, Rural Coast, Rural Inland, Suburban, Urban Coast and Urban Inland. The clustering resulted in 7 major trajectories.

Source: “Family Trajectories and Social Networks" Project, Portugal 2010

Tab. 1: $\quad$ Clusters of geographical mobility by generation and gender (\%)

\begin{tabular}{|c|c|c|c|c|c|c|c|c|c|c|c|c|}
\hline \multirow[b]{2}{*}{ Cluster } & \multicolumn{3}{|c|}{ Total } & \multicolumn{3}{|c|}{$\begin{array}{c}\text { Generation } \\
1935-1940\end{array}$} & \multicolumn{3}{|c|}{$\begin{array}{c}\text { Generation } \\
1950-1955\end{array}$} & \multicolumn{3}{|c|}{$\begin{array}{c}\text { Generation } \\
1970-1975\end{array}$} \\
\hline & $M$ & $\mathrm{~F}$ & Total & $\mathrm{M}$ & $\mathrm{F}$ & Total & $M$ & $\mathrm{~F}$ & Total & $M$ & $\mathrm{~F}$ & Total \\
\hline Suburban & 21.5 & 22.4 & 22.0 & 17.5 & 18.3 & 17.9 & 23.1 & 23.5 & 23.4 & 23.3 & 24.5 & 24.1 \\
\hline Major Cities & 9.5 & 15.1 & 12.9 & 15.8 & 19.8 & 18.2 & 10.4 & 16.3 & 13.9 & 2.9 & 10.3 & 7.5 \\
\hline Rural Inland & 9.5 & 11.1 & 10.5 & 12.0 & 16.7 & 14.8 & 9.9 & 10.5 & 10.2 & 6.8 & 7.3 & 7.1 \\
\hline Rural Coast & 7.8 & 6.0 & 6.7 & 9.8 & 8.0 & 8.7 & 9.9 & 5.2 & 7.1 & 3.9 & 5.2 & 4.7 \\
\hline Urban Inland & 18.3 & 16.1 & 17.0 & 13.7 & 16.7 & 15.5 & 15.6 & 14.4 & 14.9 & 25.2 & 17.3 & 20.3 \\
\hline \multirow{2}{*}{$\begin{array}{l}\text { Urban Coast } \\
\text { Colonies, Europe } \\
\text { and Beyond }\end{array}$} & 26.8 & 24.6 & 25.5 & 23.0 & 17.1 & 19.5 & 23.6 & 24.2 & 23.9 & 33.5 & 30.9 & 31.9 \\
\hline & 6.7 & 4.7 & 5.5 & 8.2 & 3.4 & 5.4 & 7.5 & 5.9 & 6.6 & 4.4 & 4.5 & 4.5 \\
\hline \multirow[t]{3}{*}{ Total } & 100 & 100 & 100 & 100 & 100 & 100 & 100 & 100 & 100 & 100 & 100 & 100 \\
\hline & \multicolumn{3}{|c|}{$\begin{array}{c}\mathrm{Chi}^{2}(6)=16.01 \\
p<0.05 \\
\text { Cramer's V = } 0.10\end{array}$} & \multicolumn{3}{|c|}{$\mathrm{Chi}^{2}(6)=n . s$} & \multicolumn{3}{|c|}{$\mathrm{Chi}^{2}(6)=n . s$} & \multicolumn{3}{|c|}{$\begin{array}{c}\mathrm{Chi}^{2}(6)=14.08 \\
p<0.001 \\
\text { Cramer's V }=0.16\end{array}$} \\
\hline & \multicolumn{12}{|c|}{ Inter-generational comparison: $\mathrm{Chi}^{2}(12)=70.25, p<0.001 ;$ Cramer's V $=0.15$} \\
\hline
\end{tabular}

Source: “Family Trajectories and Social Networks" Project, Portugal 2010 
nearly a quarter of the individuals residing in the suburbs of Lisbon and Porto), a slow but steady movement into the suburbs started in the older generation. Coming from rural areas to major cities, some of the older people in our sample had moved to the outskirts of the city at some point in their young adulthood, initiating a trend that gained pace over the succeeding decades and generations. The increase of this pattern in the middle generation can be easily related, in the Portuguese case, with the golden period of migration to the industrial belts that surrounded Lisbon and Porto, which took place from the late 1960s onwards. In the younger generation, the lower housing costs in the suburbs have perhaps led many to stay or move to suburban areas. This pattern is heavily influenced by generation effects, which reveal key trends of geographical reorganisation over the last few decades, in particular the emptying of larger cities and the corresponding transfer of people into the suburbs. All in all, nearly 40 percent of the individuals in this cluster have changed their place of residence at least once between the ages of 18 and 35 .

The second cluster covers individuals who lived in the two major Portuguese cities (Lisbon and Porto) for most of their early adulthood. In the middle and younger generation, this period amounts, on average, to 16 years of residence in the city between the ages of 18 and 35. A slightly different pattern characterises the older generation. Among older individuals (who lived, on average, 14 years in the city), this pattern comprises a greater proportion of people migrating after age 18 from the rural areas of the country and also from smaller cities along the coast. In fact, 57 percent of these individuals have had at least one episode of geographical mobility in their early adulthood, whereas a similar pattern includes only 27 percent of men and women in the younger generation. The major cities were, after all, a key internal migration destination for those who left rural areas, particularly in the older generation. Indeed, while 18 percent of individuals in the older generation lived in major cities, this percentage falls dramatically in the younger generation to only 7.5 percent of the interviewees in our sample.

On the other hand, there are two clusters of geographical mobility comprising individuals who spent their early adulthood in rural areas: the rural coast and the rural inland. Both patterns reveal a very low degree of geographical mobility, with individuals spending most of their lives, between the ages of 18 and 35, in the same residential areas (on average 16 years for all three generations). However, even if we can consider these types as rather immobile when we look at the biographies of individuals, an inter-generational comparison reveals a very different scenario. From this latter perspective, both types show a strong decrease, even if the pace of change is slightly different for each type. While the rural coast cluster has been shown to decrease particularly in the younger generation, the rural inland cluster clearly fell from the older to the middle generation, thus revealing the speed of the rural exodus that took place in Portuguese society from the 1960s onwards.

Our analysis revealed two other patterns which include individuals living in urban areas, or more accurately, in smaller cities, whether these urban conglomerations are located along the coast - the urban coast cluster - or inland - the urban inland cluster. The latter is clearly more mobile (with individuals living on average 15 years in inland urban areas), particularly in the older and middle generations, 
when many individuals moved from inland rural areas to more urban environments. In fact, nearly 40 percent of these individuals have experienced at least one episode of geographical mobility in their early adulthood. But, most importantly, it is across generations that we see the clear-cut trends that make both these clusters very different from the former two. While the rural patterns have decreased considerably, the urban types are, by contrast, more significant among the younger generation. As before, however, the generational comparison does show different growth trends for each pattern. The urban coast cluster - which corresponds to mediumsized towns located along the coastal strip, particularly in areas north of Lisbon and in the Algarve - has steadily increased across the generations (from 19.5 percent in the older generation to 23.9 percent in the middle generation, and finally to 31.9 percent in the younger generation). In terms of moves from one location to another, this is also the less mobile pattern, with only 24.3 percent of individuals undergoing an episode of geographical mobility. Following a different trend, the inland urban cluster slightly decreases from the older to the middle generation and then displays significant growth in the younger generation. In short, while the concentration of people in towns located along the urban coastal area reflects the enduring urbanisation of the coastal regions (littoralisation), the movement to inland cities can be seen as a more recent phenomenon in Portuguese society (Ferrão 2002).

The last cluster, which we named former colonies, Europe and beyond, covers the group of individuals who have emigrated, leaving or entering Portugal at least once in their early adulthood. Whether heading for or returning from the former Portuguese colonies in Africa, Europe or other continents, 82 percent of the individuals in this cluster have a biographical profile of geographical mobility. Overall, this pattern represents 5.5 percent of the respondents in the three-generation sample. From a generational perspective, this emigration pattern increases in the middle generation (6.6 percent) and drops to a lower percentage ( 4.5 percent) in the younger generation. However, an analysis that takes gender differences within each generation into account enables us to stress the importance of male migration when describing this pattern. If we analyse male emigration on its own, the generational flow is slightly different. The percentage of men who emigrated is higher in the older generation (those born between 1935 and 1940) than in the middle generation (8.2 and 7.5 percent, respectively). The trend is quite different in the case of women, (see Table 1). The destination countries also differ from generation to generation. In the older generation, individuals (and men particularly) emigrated to the former Portuguese colonies from age 18 to age 35 (they lived in Africa for an average of about 7.5 years). Emigration to Europe is much more pronounced in the middle generation (those born between 1950 and 1955): Individuals in this generation lived in a foreign European country for about 9.5 years. The most common movement in the younger generation is that of return to Portugal, whether coming from the former colonies or from Europe. In many cases, these men and women move to suburban areas of Lisbon and Porto (where they live for an average of about 3 years). Altogether, a generational reading of this pattern is needed to further our understanding of Portuguese emigration flows: mainly to Africa in the late 1950s and early 1960 s and then 
to Europe, a migration trend that lasted until the 1980 s and, as expected, has been a marker of the middle generation's geographical life course.

All in all, a generational comparison of these seven clusters shows that in the older generation there was greater movement from rural areas to urban locations or even to Africa and Europe. In this generation, 42 percent of the individuals have experienced at least one episode of geographical mobility, which is a higher percentage than those of the other two generations. The percentage of mobile individuals is also high in the middle generation (40 percent), whereas the decrease is quite marked in the younger generation, with only 29 percent of individuals experiencing geographical mobility (data not shown). We may thus characterise the older generation according to the strength of the rural exodus which most men and women experienced when seeking a better life in the urban areas of the country. The middle generation, as mentioned above, is characterised by a higher rate of geographical mobility in the case of men, a higher percentage of whom emigrated mainly to Europe. Although a few individuals in this generation returned from the Portuguese colonies after the 1974 revolution, European emigration and the continuous exodus from rural areas to urban locations is paramount for those born between 1950 and 1955. It is well known that these migration processes contributed to the concentration of the Portuguese population in coastal and urban areas. As a result, and as anticipated, the younger generation, raised far from the already desertified rural inland, is considerably less mobile. Even so, the younger generation is marked by a major geographical movement, suburbanisation, which increases noticeably, thus reinforcing a trend already visible in the middle generation.

Family trajectories, the second key variable in our analysis, were clustered into four main types (see Fig. 2 and Table 2). A predominant family trajectory (early parental, 45.1 percent in total) is linked to the prevalence of the nuclear family, through an early transition to conjugality and a very short interval between the beginning of a partnership and the arrival of the first child. In the older generation, individuals entered conjugal life at age 22 on average, in the middle generation at age 21.6 and in the younger generation at age 21. The first child was also born a year later on average. There is practically no childlessness in this cluster, and the same can be said of divorce or living as a single parent. This biographical pattern is quite similar for the three generations. The early parental trajectory is nonetheless subject to generational effects. While this cluster included half of the individuals in the older generation (49.8 percent) and was even more predominant in the middle generation (53.3 percent), it decreases considerably in the younger generation, with only onethird of individuals matching this type. Gender differences are pronounced across the three generations: More women than men follow an early parental trajectory.

In a second family trajectory, the extended parental, there is also very early entry into conjugal and parental life, following a pattern quite similar to the one described above. In each generation, the timings of the beginning of the conjugal and parental life stages are the same, with all couples having at least one child. The main difference is that rather than matching a nuclear family pattern, this cluster describes a couple which is part of an extended living arrangement, in which others (mostly kin) are also found. However, if we combine the two clusters together, since they 
Fig. 2: Family trajectories (under 19 to under 36 years), by cluster

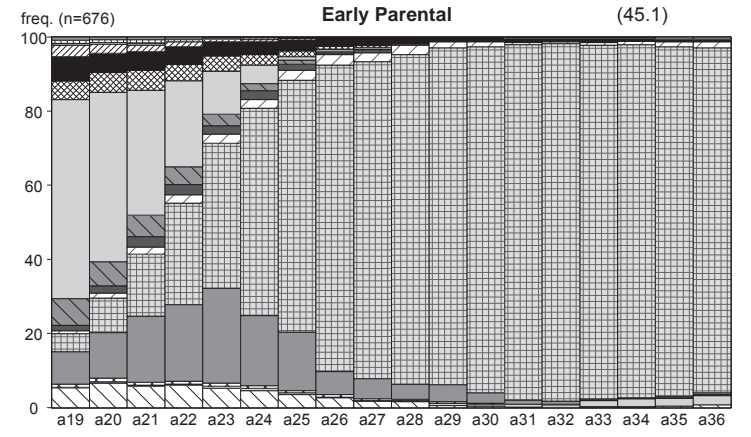

$\square$ NA

四 With siblings

$\square$ With step parents

With parents and other family

With other family

With non relatives

$\square$ With 2 parents

$\triangle$ With 1 parent

Couple with others

$\square$ Couple with children and others

困 Couple with children

Couple

None with children and others

$\square$ Alone with children

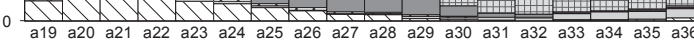

$\square$ Alone
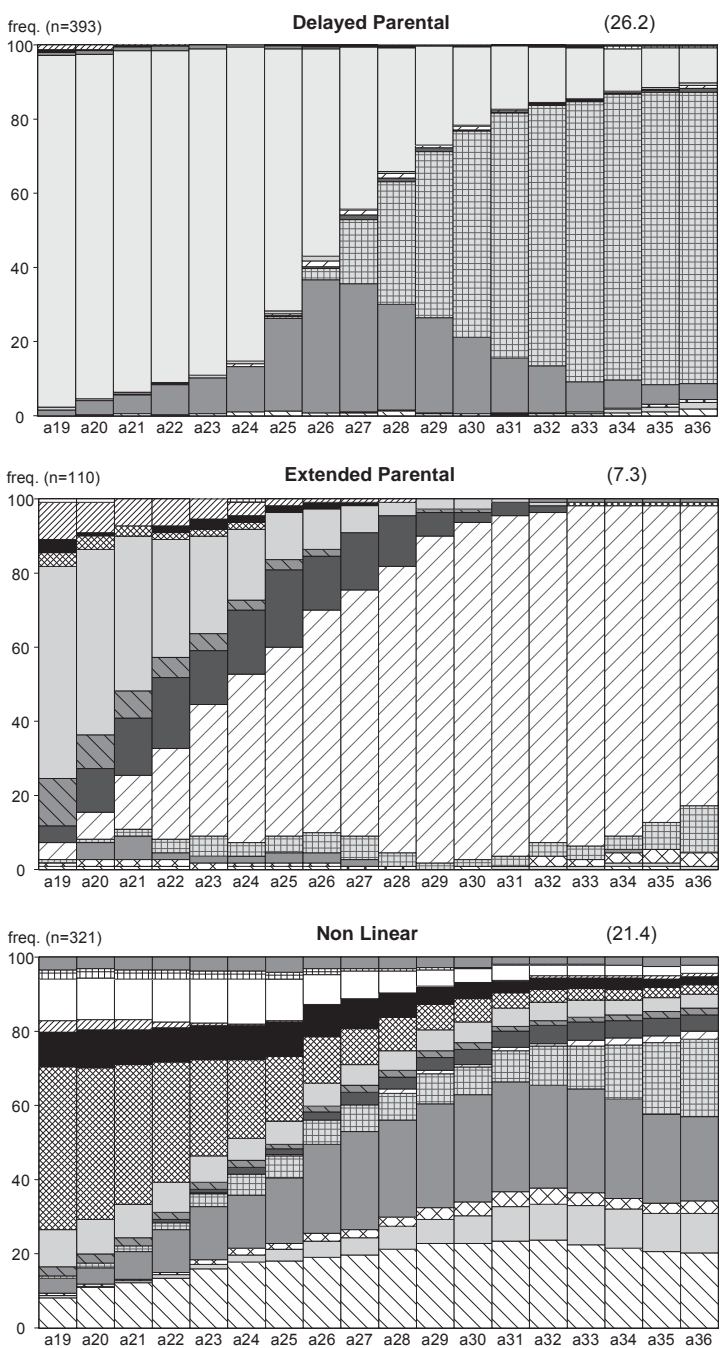

Source: “Family Trajectories and Social Networks” Project, Portugal 2010 
Tab. 2: Clusters of family trajectories by generation and gender (in \%)

\begin{tabular}{|c|c|c|c|c|c|c|c|c|c|c|c|c|}
\hline \multirow[b]{2}{*}{ Cluster } & \multirow[b]{2}{*}{ M } & \multicolumn{2}{|l|}{ Total } & \multicolumn{3}{|c|}{$\begin{array}{c}\text { Generation } \\
1935-1940\end{array}$} & \multicolumn{3}{|c|}{$\begin{array}{c}\text { Generation } \\
1950-1955\end{array}$} & \multicolumn{3}{|c|}{$\begin{array}{c}\text { Generation } \\
1970-1975\end{array}$} \\
\hline & & $\mathrm{F}$ & Total & $\mathrm{M}$ & $\mathrm{F}$ & Total & $M$ & $\mathrm{~F}$ & Total & $M$ & $\mathrm{~F}$ & Total \\
\hline Early Parental & 36.1 & 51.1 & 45.1 & 42.6 & 54.8 & 49.8 & 42.0 & 61.1 & 53.3 & 24.3 & 38.8 & 33.2 \\
\hline Extended Parental & 5.8 & 8.3 & 7.3 & 6.0 & 7.6 & 7.0 & 9.0 & 11.8 & 10.6 & 2.4 & 5.8 & 4.5 \\
\hline Delayed Parental & 35.4 & 20.0 & 26.2 & 33.9 & 18.6 & 24.9 & 30.2 & 14.7 & 21.0 & 42.2 & 26.1 & 32.3 \\
\hline Non-linear & 22.6 & 20.6 & 21.4 & 17.5 & 19.0 & 18.4 & 18.9 & 12.4 & 15.1 & 31.1 & 29.4 & 30.0 \\
\hline \multirow[t]{3}{*}{ Total } & 100 & 100 & 100 & 100 & 100 & 100 & 100 & 100 & 100 & 100 & 100 & 100 \\
\hline & \multicolumn{3}{|c|}{$\begin{array}{c}\mathrm{Chi}^{2}(3)=54.37 \\
p<0.01 \\
\text { Cramer's V }=0.19\end{array}$} & \multicolumn{3}{|c|}{$\begin{array}{c}\mathrm{Chi}^{2}(3)=13.80 \\
p<0.01 \\
\text { Cramer's V }=0.18\end{array}$} & \multicolumn{3}{|c|}{$\begin{array}{c}\mathrm{Chi}^{2}(3)=27.25 \\
p<0.001 \\
\text { Cramer's V }=0.23\end{array}$} & \multicolumn{3}{|c|}{$\begin{array}{c}\mathrm{Chi}^{2}(3)=21.59 \\
p<0.001 \\
\text { Cramer's } \mathrm{V}=0.20\end{array}$} \\
\hline & \multicolumn{12}{|c|}{ Inter-generational comparison: $\mathrm{Chi}^{2}(6)=83.77 ; p<0.001$, Cramer's $\mathrm{V}=0.17$} \\
\hline
\end{tabular}

Source: “Family Trajectories and Social Networks” Project, Portugal 2010

both involve an early start to the conjugal and parental stages of the life course, early parental patterns become even more significant. In the middle generation, the sum of these two family trajectories reveals that 64 percent of couples were able to start and raise a family at a very early age, whether living in a nuclear or extended family arrangement. Most likely, the historic opportunities generated by the expansion of industry and the economic development that marked the 1960s in Portugal, alongside migration as a catalyst for access to financial resources, allowed people to adopt a more standardised pattern of family life. In this generation, only one-third of individuals failed to follow this type of trajectory. The contrast with the younger generation is clear-cut: In this later generation, more than 60 percent of the individuals did not experience the early parental trajectory.

In the third cluster (delayed parental), which is still characterised by the predominance of the nuclear family, there are some significant differences. On the one hand, couple formation occurs later in life. Couples in all three generations start living together at around age 26 on average. On the other hand, the gap between the start of the partnership and the arrival of the first child is longer. Once again, in all three generations parenthood occurs, on average, at around age 28, and in many cases even later. Couples wait longer to have children. This pattern represented close to one in every four cases in the older generation, amounting to only 21 percent in the middle generation. In the younger generation, the delayed parental trajectory covers 32.3 percent of individuals, although gender differences are also a durable trend which has to be taken into account. In the younger generation, 42.2 percent of men follow a delayed parental trajectory, as against only 26.1 percent of women.

Our fourth and final family trajectory covers 21.4 percent of individuals from all three generations in the sample. It corresponds to what we have labelled non-linear trajectories, and clusters together a greater diversity of family trajectories. If we take all three generations into account, we find a clear breakdown in this pattern: half the individuals (and nearly 55 percent in the younger generation) did not have children between the ages of 18 and 35 . We are therefore describing a large group 
of people who are childless. And even if most of these individuals have experienced a conjugal partnership, the percentage of those who stayed single is much higher than in other family trajectories: 14 percent for the older and the middle generations and 25 percent for the younger generation. Between the ages of 18 and 35 , a significant percentage of the individuals in this pattern have also lived alone at a certain point in their lives: 22 percent in the older generation, 33 percent in the middle generation, and 52 percent in the younger generation. Separation and divorce are also more common events, ranging from 13 percent in the older generation to 20 percent in the middle and 32 percent in the younger generation. Taken together, though the majority of these individuals have embarked on conjugal life, they have remained childless in many cases and have followed less stable trajectories, frequently living alone, divorcing, or living in single parent families. As anticipated, this pattern is more significant among the younger generation (30 percent). The middle generation, where we found a higher degree of conjugal and parental standardisation, has the lowest percentage of non-linear trajectories (15.1 percent). In the older generation, this percentage was slightly higher (18.4 percent).

A few important conclusions can be drawn from our data. From a generational perspective, we can clearly associate a higher degree of standardisation with the middle generation, which formed family trajectories in accordance with an early parental model. Interestingly, this pattern is somewhat less marked in the older generation. However, the major changes appear clearly in the younger generation, which is evidently more susceptible to non-linear as well as delayed parental family trajectories.

\subsection{Linking geographical mobility and family trajectories}

Our second key goal, as described earlier, was to explore the connections between geographical mobility and family trajectories. In order to link the two trajectories, we used multinomial logistic regression models. As explained above, and aiming to measure the complex connections between migration and family life, we carried out two regression analyses, giving geographical mobility a role as both a dependent and an independent variable in our regression models. Through the operationalisation of such an analytical strategy, we were able not only to examine the impact of geographical mobility on family trajectories - our main hypothesis - but also to pinpoint the causes, in individuals' biographies and across generations, that may have led some individuals to migrate, whether heading to Portuguese urban areas or to other countries, while others stayed where they were.

In this line of reasoning, even though we were expecting geographical trajectories to have a stronger impact on family life, we started out by testing a regression model in which geographical trajectories are considered as dependent variables. The analysis was carried out for the whole sample and alongside key socio-demographic variables, such as generation, gender and the number of years spent at school. We also took into account other biographical factors, in particular the number of years of unemployment as well as the age of entry into the labour market. With respect to mobility, we included the number of changes in the places of resi- 
Tab. 3: Predictors of geographical mobility trajectories - Multinomial logistic regression (odds ratios)

\begin{tabular}{|c|c|c|c|c|c|c|}
\hline & Suburban $^{\mathrm{a}}$ & $\begin{array}{l}\text { Major } \\
\text { Cities }^{\text {a }}\end{array}$ & $\begin{array}{l}\text { Rural } \\
\text { Coast }^{\mathrm{a}}\end{array}$ & $\begin{array}{c}\text { Colonies, } \\
\text { Europe } \\
\text { and } \\
\text { Beyond }^{\mathrm{a}}\end{array}$ & $\begin{array}{l}\text { Urban } \\
\text { Inland }\end{array}$ & $\begin{array}{l}\text { Urban } \\
\text { Coast }^{\mathrm{a}}\end{array}$ \\
\hline Generation $1935-1940^{b}$ & 1.351 & $6.022 * * *$ & 1.211 & $0.302^{*}$ & 1.070 & $0.551 *$ \\
\hline Generation $1950-1955^{b}$ & 1.642 & $4.226 * * *$ & 1.409 & 0.626 & 1.172 & 0.891 \\
\hline Gender $^{c}$ & 1.316 & $0.617^{*}$ & 1.650 & 1.565 & 1.090 & $1.569 *$ \\
\hline Schooling years & $1.180 * * *$ & $1.261 * * *$ & 1.110 & $1.121^{*}$ & $1.196 * * *$ & $1.131 * *$ \\
\hline Age of entry into the labour market & $1.067^{*}$ & 1.023 & 0.974 & 1.015 & 0.999 & 1.029 \\
\hline Years unemployed & $1.592^{*}$ & $1.613^{* *}$ & $1.694^{* *}$ & $1.451^{*}$ & 1.389 & 1.409 \\
\hline $\begin{array}{l}\text { Geographical movements before } \\
\text { the age of } 18\end{array}$ & 1.417 & 1.445 & 0.944 & 1.304 & 1.291 & 0.850 \\
\hline $\begin{array}{l}\text { Number of changes in family living } \\
\text { arrangements }\end{array}$ & 0.990 & 0.949 & 1.031 & $1.154^{* * *}$ & 0.980 & $1.086^{* *}$ \\
\hline Family Trajectory: Non linear ${ }^{d}$ & 1.051 & 2.322 & 0.942 & 1.582 & 1.070 & 1.076 \\
\hline $\begin{array}{l}\text { Family Trajectory: Delayed } \\
\text { parental }^{\text {d }}\end{array}$ & 0.789 & 0.871 & 0.881 & 0.524 & 1.172 & 0.827 \\
\hline Family Trajectory: Early parental ${ }^{d}$ & 1.350 & 1.769 & 1.981 & 1.478 & 1.070 & 1.233 \\
\hline gelker & & & & & & \\
\hline
\end{tabular}

a The reference category for comparison is "Rural inland".

b The reference category for comparison is "1970-1975 generation".

c The reference category for comparison is "Female".

$\mathrm{d}$ The reference category for comparison is "Extended parental".

${ }^{*} p<0.05 ;{ }^{* *} p<0.01 ;{ }^{* * *} p<0.001$

Source: “Family Trajectories and Social Networks" Project, Portugal 2010

dence, so as to grasp to what extent the likelihood of being mobile and following a certain type of geographical trajectory in early adulthood may be related to experiences of mobility before the age of 18 . Our goal was to observe the potential impact of family trajectories on geographical mobility, and for that purpose we included the types of trajectory revealed by sequence analysis and also the overall number of changes in living arrangements from the ages of 18 to 35 . By operating with this regression model, we were able to isolate the impact of family on mobility without disregarding other key predictive factors (see Table 3).

One important conclusion must be immediately noted. Our findings show that, across generations, unemployment is a highly-relevant predictor of geographical trajectories. The rural exodus to major cities and their outskirts, which was significant for the older and middle generations' trajectories, can with a degree of certainty be associated with prolonged unemployment, and therefore with the lack of opportunities to build a better life. Interestingly, those who spent longer at school are more often able to migrate to urban areas and to other countries. When compared to individuals who spent their early adulthood in inland rural areas (our category for comparison), we can clearly see that those who were more likely to migrate already 
had higher educational qualifications. In short, the most relevant fact for all three generations is that while geographical trajectories are strongly predicted by unemployment and lack of financial resources, family life is a very poor predictor of these different types of mobility. All in all, migration and geographical trajectories were the product of structural constraints - the lack of job opportunities and the impoverishment of rural areas impelled individuals to migrate - that affected individuals in each generation.

In addition, the results also suggest that patterns of geographical mobility, particularly the movement of those heading towards the major cities in the older and middle generations, can be predicted by generational and gender coordinates, which leads us to conclude that mobility trajectories were well rooted in specific historical contexts. As expected, certain mobility trajectories are less closely associated with the younger generation in overall terms, thus pointing to the close connection between biographies and history.

Our second multinomial regression model, which defines family trajectories as the dependent variable, reveals very different findings and confirms the impact of geographical mobility on family dynamics in early adulthood (see Table 4). Even if generations are strong predictors of family trajectories, namely because the middle generation is very closely associated with the early parental trajectory, mobility variables are extremely important when it comes to explaining the diversity of family trajectories. First, it is relevant to stress that both the age at which individuals experienced their first episode of geographical mobility and the total number of movements (or episodes of mobility) after the age of 18 appear as strong predictors of family trajectories. When compared to those with a delayed parental trajectory, individuals with other family trajectories (whether early parental or non-linear) are more likely to have experienced a geographical mobility event at an early age. This result is extremely important because it enables us to grasp the complex effects of mobility on family dynamics. If migration experienced at a young age tends to increase the likelihood of having an early parental trajectory, it also operates as a predictor for non-linear trajectories (see section 4.1). Similar effects are shown by the predictive strength of the number of mobility events in early adulthood: The more an individual is mobile, the more he or she is likely to have had either an early parental or a non-linear trajectory. In short, the impact of mobility (of its timing and intensity across the life course) seems to be somewhat dualistic, insofar as it tends to promote very different family trajectories. While in some cases mobility works as a facilitator for standardised family trajectories, which reached a peak in the middle generation, in other cases it also predicts a higher probability of falling into a non-linear trajectory. Even if we know that this type is amplified in the younger generation, a similar statistical connection can be applied to all the generations in our study.

Finally, there is one other very interesting result, which once again confirms the impact of geographical trajectories upon family life. The early parental type is strongly predicted by all of the geographical trajectories, with the exception of the rural inland trajectory (our reference category for comparison). In other words, the mere fact of having lived in inland rural areas from ages 18 to 35 considerably re- 
Tab. 4: Predictors of family trajectories - Multinomial logistic regression (odds ratios)

\begin{tabular}{|c|c|c|c|}
\hline & Non-linear & $\begin{array}{l}\text { Early } \\
\text { parental }\end{array}$ & $\begin{array}{l}\text { Extended } \\
\text { parental }^{\mathrm{a}}\end{array}$ \\
\hline Generation $1935-1940^{\mathrm{b}}$ & 0.742 & $2.037^{*}$ & 0.304 \\
\hline Generation $1950-1955^{b}$ & 1.114 & $3.079^{* * *}$ & 1.670 \\
\hline Gender $^{\mathrm{C}}$ & 1.064 & $0.543^{* *}$ & 0.757 \\
\hline Schooling years & 0.960 & 0.953 & $0.873^{*}$ \\
\hline Age of entry into the labour market & 1.051 & 0.994 & 0.982 \\
\hline $\begin{array}{l}\text { Years unemployed } \\
\text { Age when geographical mobility first }\end{array}$ & 1.071 & 0.988 & 1.039 \\
\hline occurred & $0.924 * * *$ & $0.917^{* * *}$ & $0.880^{* * *}$ \\
\hline $\begin{array}{l}\text { Geographical movements before the } \\
\text { age of } 18\end{array}$ & 0.703 & 0.745 & 0.498 \\
\hline $\begin{array}{l}\text { Geographical movements after the } \\
\text { age of } 18\end{array}$ & $1.246^{*}$ & $1.281 * *$ & 1.235 \\
\hline Geographical Trajectory - Rural coast ${ }^{d}$ & 0.345 & $3.434^{*}$ & 2.723 \\
\hline Geographical Trajectory - Urban inland d & 0.889 & $3.391^{* *}$ & 4.009 \\
\hline Geographical Trajectory - Urban coast ${ }^{\mathrm{d}}$ & 1.441 & $3.692^{* *}$ & $11.281 * *$ \\
\hline Geographical Trajectory - Suburban ${ }^{d}$ & 0.903 & $2.970^{* *}$ & 4.315 \\
\hline Geographical Trajectory - Major cities ${ }^{d}$ & 1.698 & $2.629 *$ & 3.225 \\
\hline $\begin{array}{l}\text { Geographical Trajectory - Colonies, } \\
\text { Europe and beyond }\end{array}$ & 1.556 & $3.508^{* *}$ & $9.827^{*}$ \\
\hline Nagelkerke $=0.216$ & & & \\
\hline
\end{tabular}

a The reference category for comparison is "Delayed parental".

b The reference category for comparison is "1970-1975 generation".

c The reference category for comparison is "Female".

d The reference category for comparison is "Rural inland".

${ }^{*} p<0.05 ;{ }^{* *} p<0.01 ;{ }^{* *} p<0.001$

Source: “Family Trajectories and Social Networks" Project, Portugal 2010

duces the likelihood of having had an early parental trajectory. Whether individuals migrated to Portuguese urban regions or went abroad, the effect revealed by the analysis is quite clear and demonstrates the accuracy of one of our key hypotheses. That is to say, migration in many cases helped individuals to accumulate the resources or savings needed to start a family. In rural areas, poverty and the lack of opportunity have historically and across the generations prevented many individuals from entering into a conjugal partnership and starting a family (Bandeira 1996).

However, even if we found a clear connection between the rural exodus and early parental family patterns, the dual effects exerted by mobility upon family, which were hinted at by our regression analysis, are also a key trend, which we will examine in more detail in the following section. 


\subsection{Geographical mobility and individualisation trends}

In accordance with the hypotheses set out above, it is important to explore the relationships between geographical mobility and a number of key markers of individualisation processes taking place in family life (see Table 5). As we have seen, regardless of the direction of geographical movements, mobility is a significant predictor of family trajectories, though its effects reveal a dual pattern that can either promote an early parental or a non-linear family trajectory, that is a type of trajectory in which a few markers of individualisation processes are quite evident. Our focus on individualisation led us to select a number of suitable indicators in order to examine the extent to which certain geographical movements also tend to promote non-linear family trajectories: namely, the percentage of individuals who did not embark on conjugal life and become parents as well as the number of those who, in each generation, lived alone, as a single parent or were separated and divorced between the ages of 18 and 35. Finally, we also examined the connection between female domesticity (being a housewife for a period of time during young adulthood) and geographical movements.

In spite of the key role played by history in setting the macro-scenario where lives are constructed and the rapid pace of individualisation processes across generations, there are still a number of important effects that may be associated with the impact of geographical mobility on individual biographies. In other words, although generational change is striking for most of the selected indicators (see Table 5), in the transition from older to younger generations the type of geographical movement has had a visible influence on individuals' family lives. In some cases, mobility patterns have encouraged individualisation, producing a sharp contrast with the once much more common conjugalist and familialistic trajectories.

One important trend is what we may call a "city effect". Moving to and settling in major cities (Lisbon and Porto in this case) is likely to have led people to live less standardised conjugal lives. In spite of the generational differences in this geographical pattern - with more members of the older generation migrating to the city and more young adults living in the city among the younger generation - the association of major cities with non-linear family patterns is quite marked. Moreover, this is a biographical effect that cuts across the three generations, even if it is more significant for the younger individuals in our sample. In all generations, when there is high mobility, there are always fewer people entering conjugal life and having children, more individuals living alone and as lone parents or experiencing separation or divorce (particularly in the middle and younger generations). In addition, we fi nd a lower percentage of housewives in all the generations.

Among those who stayed in inland rural areas, the percentage of individuals in the older and middle generations who were not able to embark on conjugal life is also significantly above average. Nevertheless, these biographies can hardly be described as non-linear family trajectories. These individuals were excluded from conjugal life because they were unable to find suitable partners and start families. Imbalances generated by migration (male migration in particular) and extreme poverty were the main underlying causes, and these can hardly be associated with 
Tab. 5: Geographical mobility trajectories and individualisation markers (age 18-35), by generation (in \%)

\begin{tabular}{|c|c|c|c|c|c|c|c|}
\hline Cluster & Generation & $\begin{array}{c}\text { Individuals } \\
\text { without } \\
\text { conjugal life }\end{array}$ & $\begin{array}{l}\text { Childless } \\
\text { individuals }\end{array}$ & $\begin{array}{l}\text { Lived } \\
\text { alone }\end{array}$ & $\begin{array}{l}\text { Lived as } \\
\text { lone parent }\end{array}$ & $\begin{array}{l}\text { Divorced/ } \\
\text { separated }\end{array}$ & $\begin{array}{c}\text { Women in } \\
\text { domestic } \\
\text { work }\end{array}$ \\
\hline \multirow[t]{3}{*}{ Total } & 1935-1940 & $9.9 * * *$ & $15.5^{* * *}$ & $9.6 * * *$ & $7.0^{* *}$ & $9.0^{* * *}$ & $19.7^{* * *}$ \\
\hline & 1950-1955 & $9.1 * * *$ & $13.9 * * *$ & $13.1 * * *$ & $6.6 * *$ & $6.8 * * *$ & $14.3^{* * *}$ \\
\hline & 1970-1975 & $17.4 * * *$ & $26.5^{* * *}$ & $21.6 * * *$ & $11.8 * *$ & $14.0 * * *$ & $6.7 * * *$ \\
\hline \multirow[t]{3}{*}{ Rural Inland } & $1935-1940$ & 15.2 & 12.1 & 9.1 & 12.1 & $15.2^{*}$ & 24.2 \\
\hline & 1950-1955 & 17.0 & 13.2 & 7.5 & 0.0 & $0.0^{*}$ & 17.0 \\
\hline & $1970-1975$ & 15.8 & 13.2 & 7.9 & 7.9 & $15.8^{*}$ & 13.2 \\
\hline \multirow[t]{3}{*}{ Rural Coast } & $1935-1940$ & 10.3 & 10.3 & 2.6 & 5.1 & 5.1 & 10.3 \\
\hline & 1950-1955 & 8.1 & 10.8 & 10.8 & 8.1 & 8.1 & 16.2 \\
\hline & $1970-1975$ & 8.0 & 12.0 & 4.0 & 12.0 & 8.0 & 16.0 \\
\hline \multirow[t]{3}{*}{ Urban Inland } & $1935-1940$ & $8.7 * * *$ & $8.7^{* * *}$ & $10.1^{* *}$ & 5.8 & 5.8 & 20.3 \\
\hline & 1950-1955 & $7.8^{* * *}$ & $15.6^{* * *}$ & $22.1^{* *}$ & 7.8 & 2.6 & 13.0 \\
\hline & $1970-1975$ & $26.6 * * *$ & $36.7^{* * *}$ & $33.0^{* *}$ & 5.5 & 5.5 & 8.3 \\
\hline \multirow[t]{3}{*}{ Urban Coast } & $1935-1940$ & $3.4^{*}$ & $13.8^{* * *}$ & 12.6 & $4.6^{*}$ & $9.2^{*}$ & 17.2 \\
\hline & 1950-1955 & $5.6^{*}$ & $8.9 * * *$ & 12.9 & $5.6^{*}$ & $5.6^{*}$ & 16.1 \\
\hline & $1970-1975$ & $12.9 *$ & $26.3^{* * *}$ & 21.6 & $12.9 *$ & $15.8^{*}$ & 4.7 \\
\hline \multirow[t]{3}{*}{ Suburban } & $1935-1940$ & 8.7 & 18.7 & 8.8 & 10.0 & 10.0 & 26.3 \\
\hline & $1950-1955$ & 9.9 & 13.2 & 12.4 & 6.6 & 9.1 & 10.7 \\
\hline & $1970-1975$ & 13.2 & 22.5 & 15.5 & 12.4 & 15.5 & 3.1 \\
\hline \multirow[t]{3}{*}{ Major Cities } & $1935-1940$ & $14.8^{* *}$ & 23.5 & $7.4^{* *}$ & 4.9 & 6.2 & 16.0 \\
\hline & 1950-1955 & $9.7^{* *}$ & 26.4 & $9.7^{* *}$ & 11.1 & 9.7 & 13.9 \\
\hline & 1970-1975 & $35.0 * *$ & 42.5 & $27.5^{* *}$ & 17.5 & 17.5 & 2.5 \\
\hline Colonies, Europe & $1935-1940$ & 8.3 & 20.8 & 25.0 & 4.2 & 12.5 & 20.8 \\
\hline \multirow[t]{2}{*}{ and beyond } & 1950-1955 & 8.8 & 8.8 & 20.6 & 5.9 & 14.7 & 17.6 \\
\hline & $1970-1975$ & 12.5 & 12.5 & 33.3 & 25.0 & 29.2 & 20.8 \\
\hline
\end{tabular}

Inter-generational comparison using $\mathrm{Chi}^{2}$ test: ${ }^{*} p<0.05 ;{ }^{* *} p<0.01 ;{ }^{* *} p<0.001$

Source: "Family Trajectories and Social Networks" Project, Portugal 2010

individualisation. On the contrary, permanent celibacy was not uncommon in rural communities, where public respectability was important and constantly in the public eye (particularly, of course, for women) (Wall 1998). Those who failed to meet these standards - and it should be noted that a high percentage of separated or divorced individuals is a marker of this group in the older generation, perhaps as a result of migration - frequently lived outside the bounds of the normative family model. In fact, stigmatisation and shame often accompanied these less normatively standardised events. Conversely, the "urban experience" (Martuccelli 2006) represented, in many cases, almost the diametric opposite of this community controlled celibacy insofar as it allowed individuals to experience a higher degree of freedom with regard to their private choices and family biographies.

The more recent flow of migration to inland urban or coastal areas (which increased in the younger generation) reinforces the importance of the "urban experience" for the further understanding of processes of individualisation. In the younger 
generation, the postponement of conjugal and parental transitions as well as the experience of having lived alone between the ages of 18 and 35 became more common, in particular among those individuals who lived in inland urban areas during this period of young adulthood. The combination of two factors which fundamentally altered Portuguese society from the late 1980s onwards probably accounts for individuals postponing such family events. The new and rapid expansion of higher education at this time paved the way for new forms of migration. On the one hand, there was an increase in the number of universities and other institutions of higher education. They relocated to medium-sized inland cities, and even to smaller towns, in order to avoid an excessive concentration of universities in major cities. On the other hand, the number of students in the universities also increased considerably, with a growing number of individuals attending university in these newly-established institutions. In short, broader geographical and class-based access to higher education contributed significantly to reinforcing the trend towards individualisation. Young individuals were then allowed to migrate in order to pursue their career goals. Such opportunities led many to live alone and to postpone partnership and parenthood. Displacement and relocation are therefore inseparable from the changes that took place in education strategies, particularly among younger individuals who benefited from this historic process of democratisation. All in all, the lengthening of school careers and relocation to urban settings are deeply interwoven processes which have contributed strongly to the growth of more individualised family biographies.

Lastly, alongside the paramount importance of the urban experience, the effects of experiences of intense migration (such as those experienced by individuals who emigrated to or returned from the former colonies, Europe and beyond) are equally relevant to an understanding of individualisation in Portuguese society. As we have already seen, intense migration has a dualistic effect on family trajectories. Individuals with a geographical pattern of intense migration (from or to the colonies, Europe and beyond) have a very interesting profile (see Table 5). Across the generations, the great majority of these individuals have indeed embarked on conjugal and parental life. These indicators confirm the hypothesis that migration is associated with the opportunity of starting a family, but this is just one side of the coin. The experience of intense migration has also produced a number of other transitions and experiences that we normally associate with processes of individualisation in family life. Indeed, starting with the older generation, highly-mobile individuals are those who have most often lived alone.

Episodes such as living alone, as a single parent, or going through a divorce or separation before the age of 35 were relatively rare among people born between 1935 and 1940. Yet these episodes were far more common among those who migrated than among those who stayed behind. In the younger generation, the number of individuals who lived as single parents or experienced separation and divorce is also considerably above the average. These numbers clearly show the association of intense migration with non-linear family trajectories, even if migration can also be seen as a catalyst for starting conjugal life and parenthood at an early age. Interestingly, however, while the "urban experience" tends to encourage women to 
enter the labour market, trajectories of intense migration such as those profiled in our cluster analysis seem to promote an increase in female domesticity in young adulthood. Once again, there are two sides to this phenomenon. For some, intense migration was linked to a historical context in which early parental trajectories led to lower employment rates for mothers. It should be noted, for instance, that in the middle generation these intense migration trajectories were very closely associated with early parental trajectories, with 70 percent of those who migrated to the former colonies, Europe or other host countries falling into this family pattern (data not shown). On the other hand, the succession in time of several episodes of mobility, alongside the increased non-linearity of many family trajectories, may well have led women to stay at home for a certain period of time.

\section{$5 \quad$ Discussion and conclusions}

In modern times, in contexts of industrialisation and urbanisation, migration has played an important role in the strengthening of key processes of individualisation (Elias 1993). From the early twentieth century onwards, the increasing flows of intercontinental migrants have seen their traditional familistic social environments broken down by their own geographical mobility, which allowed them to reconstruct their lives, families and ties away from their villages of origin. Similarly, the massive movements from the countryside to the city, though internal within a country, produced a similar overall effect in family life and social relations. Modern migratory processes draw us into one of the most compelling debates in the social sciences, which has focused on the idea that "community control" would fade with modernisation, giving way to more individualised relationships, far from wider kinship, neighbourhood ties and traditional alliances. Theories of community decline have been posited since the beginning of sociology, as a result of the founding fathers' concern with the impact of modernity on the formation of social ties. The subject was enshrined in Ferdinand Tönnies' (1957 [1887]) celebrated distinction between pre-modern Gemeinschaft (community) and modern Gesellschaft (society), and in Emile Durkheim's (1978 [1893]) famous distinction between "mechanical" and "organic" solidarity. From this perspective, migrations are indelibly linked to the changing patterns of conjugal and family dynamics (Shorter 1995), though promoting, as we have seen, different and somewhat complex changes in family life.

In this line of reasoning, and taking into account the specificities of Portuguese history, this article found empirical evidence for the hypotheses outlined at the beginning. On the one hand, geographical mobility tended to promote individuals' access to conjugal and family life, but, on the other, it also paved the way for more individualised biographies and more non-linear family trajectories. Both phenomena confirm that migratory processes, whether internal within the country or heading abroad, have been one of the central dynamics in the construction of Portuguese modernity and have underpinned the changes in family dynamics across time. For this reason, we believe that our study may contribute to the further understanding of the connections between geographical mobility and family trajectories across 
generations. The impact of mobility on family life was an important conclusion drawn from our data. The dual impact of mobility was also an extremely important finding.

A fruitful way of achieving such goals was to develop a life course approach, which allowed us to examine both generational change and biographical trajectories on the basis of sequence analysis.

The diversity of mobility trajectories revealed by sequence analysis was found to be relevant for locating each generation in its historical time. From a comparative perspective, as anticipated, generations are important for interpreting predominant mobility patterns at a given historical moment and among specific groups of individuals. In this first set of conclusions related to the impact of history on biographies, we can highlight two clear-cut trends across generations.

On the one hand, Portuguese society has witnessed a significant rural exodus over time. To this day, that exodus remains an important marker of mobility life courses, and it is common to the three generations in our study, in spite of their differences. In every generation, large numbers of men and women have moved to urban areas, both to small cities and to the two major cities Lisbon and Porto. A variety of factors, ranging from changes in the country's economic structure to longer school careers, have helped to sustain this geographical movement over time and to the present day.

On the other hand, while rural exodus represents a significant generational similarity, there are also some key generational differences. First, there has been a clear increase in suburbanisation among the younger generation. Younger individuals are often compelled to move from major cities to the suburbs (where, for instance, the costs of housing are much lower), even if the process is very different from the one pointed out by Castel/s (1983) when analysing the wealthy suburbia of countries such as the US. Secondly, migrants have returned from the former colonies and from different European and non-European countries. For historical reasons, a larger number of former emigrants who have returned en masse is found among the older and middle generations. Finally, more members of the younger generation are tending to stay put, even if our findings reveal that geographical mobility has been a key marker of the life course for large numbers of individuals in every generation.

We offer a second important set of conclusions on the impact of mobility on family life. The results of our multinomial logistic regressions show consistent connections between the two trajectories, attesting to the importance of geographical mobility as a predictor of family dynamics. Our findings show a steady correlation between geographical mobility, family trajectories and family transitions across the generations. To interpret these findings, we need to consider the historical processes of individualisation and pluralisation. Generational coordinates are clearly important when it comes to analysing the impact of geographical mobility on the family. Overall, mobility helped to sustain a standardised early parental family pattern, which was particularly significant in the middle generation. During their young adulthood, almost two-thirds of these individuals fell into this pattern, thus establishing a clear contrast with the older generation, in which individuals were less likely to meet the normative demands of the conjugal and parental family models. 
However, the contrast between the two older generations and the younger generation is sharper in every respect: It is among the latter group of individuals that we find only one-third of early parental trajectories. The increase in delayed parental and non-linear trajectories is paramount.

Building on the changes that affected and were enacted by the two previous generations, the younger generation continues, nonetheless, to suffer from the impact of geographical mobility. In fact, some of the more recent phenomena taking place in family patterns can only be fully explained through the long-lasting effects of the geographical reorganisation of the country, whether younger individuals are themselves the protagonists of mobility episodes or just built their family lives around the changes that linger from earlier historical times and the older generations.

All in all, there are two key processes underlying the different patterns of migration in our study, both of which are of key importance for interpreting the movement of family individualisation in Portuguese society over time.

The first is the "city effect" or the "urban experience". The rural exodus that led to an "urban experience" was a major turning point in their lives for the majority of people. As Martuccelli (2006) points out, life in the city became a formative element in most individuals' biographies, due to the many ways in which this experience represented a challenge to traditional ways of life. As in other Western contexts, this was perhaps the most common migratory process in Portuguese society, although the fact that it occurred later than in other countries reflects Portugal's structural backwardness and delayed modernisation. Until the 1960s, the majority of Portuguese worked in agriculture, but as the effects of industrialisation became clear in the 1950s, new job opportunities arose in the emerging industrial sector. Entire families moved to the rapidly developing urban areas in search of a better life. For those coming from traditional poor peasant contexts, the urban experience led to profound changes in family organisation. Whether the whole family or just one individual migrated, the move to urban areas within the country produced major changes in family dynamics and in the gender division of labour, particularly as more women entered the labour market, a phenomenon which was more visible in the major cities (see Table 5). As Elizabeth Bott (1957) has shown for the US of the 1950s, the weakening of social (local community) and family control also produced new and more modern conjugal dynamics, even if migration to lower class neighbourhoods did reproduce community control and the lost rural environment in some cases, particularly when the migration involved an openly familial strategy.

The second key process involves the complex effects of intense migration trajectories. The experience of early and intense migration is clearly connected to a number of other transitions and experiences that we normally associate with processes of individualisation in family life. Indeed, starting with the older generation, highly mobile individuals are those who have most often experienced life events such as living alone, as a single parent or going through a divorce or separation. Nevertheless, to explore the effects of mobility on family dynamics we have to go beyond the mere fact of being a mobile individual. Seen in the context of different mobility trajectories and the historical processes of geographical mobility, the impact of mobility is more complex and produces less clear-cut or even dualistic 
effects. For example, despite having contributed to encouraging biographical individualisation across the generations, intense migration has also encouraged standardisation of the life course, in particular in the middle and older generations, when rural exodus coincided with new opportunities for family formation through early parental trajectories. In summary, a major conclusion of this study is not only that mobility is an appropriate, if complex, predictor of family dynamics, but also that in order to understand the effects of mobility, it is essential to take into account social and historical pathways.

\section{References}

Abbott, Andrew 2001: Time Matters: On Theory and Method. Chicago: The University of Chicago Press [doi: 10.1177/0049124102239082].

Alwin, Duane F.; McCammon, Ryan J. 2003: Generations, Cohorts, and Social Change. In: Mortimer, Jeylan. T.; Shanahan, Michael J. (Eds.): Handbook of the Life Course. New York: Kluwer Academic/Plenum Publishers: 23-49.

Arroteia, Jorge C. 1983: A Emigração Portuguesa. Suas Origens e Distribuição. Lisboa: Instituto de Cultura e Língua Portuguesa.

Arroteia, Jorge C. 2001: As comunidades portuguesas no mundo. In: Janus 2001: 136-137.

Baganha, Maria l.; Marques, José C.; Góis, Pedro 2004: The Unforeseen Wave: Migration from Eastern Europe to Portugal. In: Baganha, Maria l.; Fonseca Maria L. (Eds.): New Waves: Migration from Eastern to Southern Europe. Lisbon: Luso-American Foundation: 23-39.

Bandeira, Mário Manuel L. 1996: Demografia e Modernidade: Família e Transição Demográfica em Portugal. Lisboa: INMC.

Beck, Ulrich 2000: Living Your Own Life in a Runaway World: Individualization, Globalization, and Politics. In: Hutton, Will; Giddens, Anthony (Eds.): Global Capitalism. New York: The New Press: 164-74.

Bott, Elizabeth 1976 [1957]: Família e Rede Social. Papéis, normas e relacionamentos externos em famílias urbanas comuns. Rio de Janeiro: Francisco Alves.

Castel/s, Manue/ 1983: The City and the Grassroots: A Cross-Cultural Theory of Urban Social Movements. Berkeley: University of California Press.

Corsten, Michael 1999: The time of generations. In: Time \& Society 8: 211-29 [doi: 10.1177/0961463X99008002003].

Durkheim, Émile 1978: De la division du travail social, Paris: P.U.F.

Elder, Glen H. (Eds.): 1985: Life Course Dynamics: Trajectories and Transitions, 1968-1980. New York: Cornell University.

Elder, Glen H. 1994: Time, human agency, and social change. In: Social Psychology Quarterly 57: 4-15.

Elder, Glen H. Jr.; Johnson, Monica K.; Crosnoe, Robert 2003: The Emergence and Development of the Life Course. In: Mortimer, Jeylan T.; Shanahan, Michael J. (Eds.): Handbook of the Life Course. New York: Kluwer: 3-19.

Elias, Norbert 1993 [1939 to 1987]: A Sociedade dos Indivíduos. Lisboa: Dom Quixote. 
European Foundation for the Improvement of Living and Working Conditions 2005: Fourth European Working Conditions Survey. Luxembourg: Office for Official Publication of European Communities.

Eyerman, Ron; Turner, Bryan S. 1998: Outline of a theory of generations. In: European Journal of Social Theory 1,1: 91-106 [doi: 10.1177/136843198001001007].

Ferrão, João 2002: Portugal, Três Geografias em Recombinação: Espacialidades, Mapas Cognitivos e Identidade Territoriais. In: Lusotopie 2: 151-158 [http://www.lusotopie. sciencespobordeaux.fr/ferrao.pdf].

Gabadinho, Alexis; Ritschard, Gilbert; Studer, Matthias.; Müller, Nicolas S. 2008: Mining sequence data in $\mathrm{R}$ with the TraMine package: A user's guide. Geneva: University of Geneva.

Gauthier, Jacques-Antoine; Widmer, Eric D.; Bucher, Philipp; Notredame, Cédric 2009: How Much Does It Cost? Optimization of Costs in Sequence Analysis of Social Science Data. In: Sociological Methods \& Research 38,1: 197-231 [doi: 10.1177/0049124109342065].

Geist, Claudia; McManus, Patricia A. 2008: Geographical mobility over the life course: motivations and implications. In: Populations Space and Place 14: 283-303 [doi: 10.1002/psp.508].

Green, Anne E.; Canny, Angela 2003: Geographical Mobility: Family Impacts. Bristol: The Policy Press [doi: 10.1080/14036090310017663].

Kertzer, David I. 1983: Generation as a Sociological Problem. In: Annual Review of Sociology 9: 125-149 [doi: 10.1146/annurev.so.09.080183.001013].

Kulu, Hill; Milewski Nadja 2007: Family change and migration in the life course: an introduction. In: Demographic Research 17,19: 567-590 [doi: 10.4054/DemRes.2007.17.19].

Limmer, Ruth; Schneider, Norbert F., 2008: Studying Job-Related Spatial Mobility in Europe. In: Schneider, Norbert F.; Meil, Gerardo: Mobile Living Across Europe I. Relevance and Diversity of Job-Related Spatial Mobility in Six European Countries. Opladen: Barbara Budrich Publishers: 13-45.

Mannheim, Karl 1952 [1927]: The problem of generations. In: Kecskemeti, Paul (Eds.): Essays on the sociology of knowledge. London: Routledge \& Kegan Paul: 276-320.

Marques, José Carlos 2008: Os Portugueses na Suíça: Migrantes Europeus. Lisbon: Imprensa de Ciências Sociais.

Martuccelli, Danilo 2006: Forgé par l'épreuve. L'individu dans la France contemporaine. Paris: Armand Colin.

Massey, Douglas S. 1988: Economic Development and International Migration in Comparative Perspective. In: Population and Development Review 14,3: 383-413.

Mayer, Karl Ulrich 2004: Whose Lives? How History, Societies, and Institutions Define and Shape Life Courses. In: Research in Human Development 1,3: 161-87 [doi: http:// www.yale.edu/ciqle/PUBLICATIONS/Mayer-WhoseLives.pdf].

Menard, Scott 2002: Applied Logistic Regression Analysis. Thousand Oaks: Sage Publications.

Peixoto, João 1999: A emigração. In: Bethencourt Francisco; Chaudhuri, Kirti (Eds.): História da Expansão Portuguesa (vol. V). Lisbon: Círculo de Leitores: 152-181.

Pires, Rui Pena et al. 1987: Os retornados - Um estudo sociográfico. Lisboa: Instituto de Estudos para o Desenvolvimento.

Pires, Rui Pena 2002: Mudanças na imigração: uma análise das estatísticas sobre a população estrangeira em Portugal 1998-2001. In: Sociologia, Problemas e Práti- 
cas 39: 151-166 [doi: http://www.scielo.gpeari.mctes.pt/scielo.php?script=sci_ arttext\&pid=S0873-65292002000200008\&lng=pt\&nrm =iso].

Ritschard, Gilbert; Gabadinho, Alexis; Müller, Nicolas S; Studer, Matthias 2008: Mining event histories: A social science perspective. In: International Journal of Data Mining, Modelling and Management 1,1: 68-90 [doi: http://dx.doi.org/10.1504/IJDMMM.2008.022538].

Rocha-Trindade, Maria Beatriz 1984: La sociologie des migrations au Portugal. In: Current Sociology 32,2: 175-198.

Sapin, Marlène; Spini, Dario; Widmer, Éric D. 2007: Les parcours de vie: de l'adolescence au grand âge. Lausanne: Savoir Suisse.

Serrão, Joe/ 1985: Notas sobre a emigração e mudança social no Portugal contemporâneo. In: Análise Social 21, 87-88-89: 995-1004.

Shorter, Edward 1995 [1975]: A Formação da Família Moderna. Lisboa: Terramar.

Silva, Maria Beatriz Nizza da 1992: Documentos para a História da Emigração Portuguesa no Brasil (1850-1938). Rio de Janeiro: Nórdica.

Tönnies, Ferdinand 1957: Community and Association. Michigan: Michigan State University Press.

Wall, Karin 1982: A outra face da emigração: estudo da situação das mulheres que ficam no país de origem. Lisboa: PCM.

Wall, Karin 1998: Famílias no Campo. Passado e Presente em duas Freguesias do Baixo Minho. Lisboa: D. Quixote - Colecção Portugal de Perto.

Wall, Karin (Eds.) 2005: Famílias em Portugal. Lisboa: Imprensa de Ciências Sociais.

White, Harrison C. 1992: Succession and generations: Looking back on chains of opportunity. In: Becker, Henk A. (Eds.): Dynamics of cohort and generations research. Amsterdam: Thesis Publishers: 31-51. 
A German translation of this reviewed and authors' authorised original article by the Federal Institute for Population Research is available under the title "Räumliche Mobilität und Familienleben: Generationenvergleich aus der Lebenslaufperspektive", DOI 10.4232/10.CPoS-2013-11de or URN urn:nbn:de:bib-cpos-2013-11de1, at http://www.comparativepopulationstudies.de.

Dr. Karin Wall. Institute of Social Sciences (ICS), University of Lisbon. Lisbon, Portugal. E-Mail: karin.wall@ics.ul.pt

URL: http://www.ics.ul.pt/investigadores/? In =e\&pid=59\&mm =1\&ctmid = $1 \& \mathrm{mnid}=1 \& \mathrm{doc}$ $=\& \sec =3$

Dr. Sofia Aboim. Institute of Social Sciences (ICS), University of Lisbon. Lisbon, Portugal. E-Mail: sofia.aboim@ics.ul.pt

URL: http://www.ics.ul.pt/investigadores/?sofia.aboim

Vasco Ramos $(\varangle)$. Institute of Social Sciences (ICS), University of Lisbon. Lisbon, Portugal. E-Mail: vasco.ramos@ics.ul.pt,

Cátia Nunes. INE - National Statistical Institute. Lisbon Portugal.

E-Mail: catia.nunes@ine.pt 


\section{Comparative Population Studies - Zeitschrift für Bevölkerungswissenschaft}

wWw.comparativepopulationstudies.de

ISSN: 1869-8980 (Print) - 1869-8999 (Internet)

Published by / Herausgegeben von

Prof. Dr. Norbert F. Schneider

Federal Institute for Population Research

D-65180 Wiesbaden / Germany

Managing Editor /

Verantwortlicher Redakteur

Frank Swiaczny

Assistant Managing Editor /

Stellvertretende Redakteurin

Katrin Schiefer

Language \& Copy Editor (English) /

Lektorat \& Übersetzungen (englisch)

Amelie Franke

Copy Editor (German) /

Lektorat (deutsch)

Dr. Evelyn Grünheid

\section{Layout / Satz}

Beatriz Feiler-Fuchs

E-mail: cpos@bib.bund.de

\author{
Scientific Advisory Board / \\ Wissenschaftlicher Beirat \\ Jürgen Dorbritz (Wiesbaden) \\ Paul Gans (Mannheim) \\ Johannes Huinink (Bremen) \\ Marc Luy (Wien) \\ Clara H. Mulder (Groningen) \\ Notburga Ott (Bochum) \\ Peter Preisendörfer (Mainz)
}

\section{Board of Reviewers / Gutachterbeirat} Martin Abraham (Erlangen)

Laura Bernardi (Lausanne) Hansjörg Bucher (Bonn) Claudia Diehl (Göttingen) Andreas Diekmann (Zürich) Gabriele Doblhammer-Reiter (Rostock) Henriette Engelhardt-Wölfler (Bamberg) E.-Jürgen Flöthmann (Bielefeld) Alexia Fürnkranz-Prskawetz (Wien) Beat Fux (Zürich) Joshua Goldstein (Rostock) Karsten Hank (Köln) Sonja Haug (Regensburg) Franz-Josef Kemper (Berlin) † Michaela Kreyenfeld (Rostock) Aart C. Liefbroer (Den Haag) Kurt Lüscher (Konstanz) Dimiter Philipov (Wien) Tomáš Sobotka (Wien) Heike Trappe (Rostock) 